\title{
Factors explaining the changes in the rankings of Polish cities' economic position (1992-2013)
}

\begin{abstract}
A nation's economic potential is always concentrated within cities. Polish cities were faced with quite radical changes in the last two decades. During this period, some cities saw losses of more and more citizens and were not ready to develop new economic approaches. Other cities were able to attract both people and businesses. The main objective of the article is to identify the changes in the economic position of Polish cities and the factors which were the driving forces behind them (including, in particular, the role of European integration). Results of the conducted regression analyses confirm that it is easier to identify "losing" factors (e.g. dependency on declining industry) than "winning" ones (as they are more individualized and more difficult to capture in statistical models). The availability of EU funds for local governments has been confirmed to be a significant factor explaining the changes in the economic position of Polish cities.
\end{abstract}

Keywords

Local government $\cdot$ local economic development $\bullet$ urban rankings $\bullet$ factors of development • European integration

(c) University of Warsaw - Faculty of Geography and Regional Studies
Julita Łukomska

Department of Local Development and Policy, Faculty of Geography and Regional Studies, University of Warsaw, Poland e-mail: j.lukomska@uw.edu.p

Received: 28 July 2017

Accepted: 26 January 2018
Introduction

A nation's economic potential is always concentrated within cities. Therefore, the development of cities and the debate on possible political strategies for improving urban economic development are especially relevant for countries or regions whose economy falls behind, like the former socialist countries in Central and Eastern Europe (CEE). Cities in all CEE countries have been subject to quite drastic changes during the last two decades, since the start of the transition from socialist to market oriented systems. Domestic institutional changes, like the reintroduction of local autonomy for cities, took place in parallel with the process of European integration. The process of integration has not had a uniform impact on the economic development of cities, and this might have resulted in changes in their economic position.

For some cities in CEE, European integration will have led to a more favorable economic development, as compared to all cities within a country or region; for other cities, the impact of integration will have been unfavorable. It is quite obvious that European integration has led to an increase in locational competition between cities (Cheshire 1999). Undoubtedly, these processes are embedded in the general tendencies of globalization.

Poland, compared to other CEE countries, is a large country with many urban areas. This is a considerable advantage with regard to quantitative analyses. Poland entered the EU in 2004. The formal process of integration was gradual. Polish cities had time to adjust their economy to the conditions within the EU.

When analyzing the development of Polish cities in the last two decades, significant changes in their economic position come to the fore. Some cities lost large numbers of citizens and were not ready to develop new economic perspectives. Other cities were able to attract both people and businesses. But, so far, the empirical analysis of the impact of European integration on this development has not been sufficient. This article aims to fill the blank spaces.

The article is organized into five key sections. The first part provides a brief overview of selected studies on factors influencing the economic development of cities and regions (including in particular measures on European integration). In the second section, the research question and hypotheses are presented. Section three is devoted to methods used in empirical tests. The next two sections present and discuss the empirical results. In the last section, the conclusions from the conducted research are presented.

\section{Review of previous studies}

With regard to economic theories on the impact of integration on regional development, good summaries are given by Niebuhr and Stiller (2004). According to them, the theoretical view that border regions may profit from integration due to the now closer distance to economic centers, highlights only one aspect. The authors show that such positive developments are scarce, and the process of integration remains open with regard to its results for particular regions. Bröcker (2009) analyzes the consequences of economic integration only for cities with the highest levels of urban hierarchies. The study on Leipzig and Wrocław by Kunze and Lenk (2007) presents a broad approach for explaining differences in the long-term development of cities, but it was not aimed to present a quantitative analysis. 
Cuaresma et al. (2014) tested the impact of 48 variables on the economic growth of 255 NUTS2 regions in the European Union between 1995 and 2005, using econometric models. The results of their research indicate the importance of education $(10 \%$ increase in the share of workers with higher education is associated with a $0.4 \%$ higher growth rate of annual GDP per capita) and location of the capital city within the region. The latter factor is particularly important in CEE countries (regions with capital cities grew on average 1.8 percentage points faster than other regions).

Noseleit (2013), analyzing data for German regions (NUTS3) between 1975 and 2002, came to the conclusion that changes in the structure of the region's economy are an important element in moving from entrepreneurial activity to real economic growth in the region. In regions with a low sectoral diversification of the economy, with the dominance of industry, the development of local entrepreneurship is not associated with economic growth as much as in regions with a more diversified economic structure.

Cullinan et al. (2013) investigated the determinants of relative economic performance for Irish towns (using a data set of 112 Irish towns with over 1000 inhabitants). Their results suggest that these determinants of success can act in different ways for different groups of towns. The dependent variable is a retail turnover per head of population. The group of independent variables consists of connectivity, capacity and competitiveness of the town. Authors construct models for different groups and also a model for all cities. In all cases, education has a positive association with relative retail performance.

There is extensive Polish literature on the organization of EU funds and its impact on regional economic development; however, these works are focused on regional rather than on urban issues (see, e.g. Ministerstwo Rozwoju Regionalnego 2010). In addition, the existing Polish literature usually concentrates on the absorption of funds, and not on a wider European integration context. The results of the latest work on the role of nationally managed programmes (EU funds) in financing local government projects show that the largest beneficiaries are especially large cities (Swianiewicz et al. 2013). The development of Polish cities is well documented with regard to demographic issues and economic key indicators (see, e.g. Węclawowicz et al. 2010), state control functions (Śleszyński 2007), spatial distribution of large enterprises (Śleszyński 2008) and location decisions made by foreign investors in Polish municipalities (Dziemianowicz 2008) or issues of polycentricity (Gorzelak \& Olechnicka 2009). One observation is that in general, the economic development of cities drops as one moves from west to east of Poland. Łukomska (2012) used regression models for all Polish municipalities to investigate factors of local economic development between 1995 and 2008. The results show that factors which may be directly influenced by local governments (like expenditures related to the improvement of local infrastructure, often with the contribution of EU funds) play a certain role in local development processes, although they do not dominate. However, the issue of European integration is hardly touched upon in these publications.

\section{Research questions and hypotheses}

The main objective of the research is the identification of the changes in the economic position of large Polish cities in 1992-2013 and an attempt to answer the question: which cities had the chance to improve their economic position, and which cities lost population and economic potential since 1992? The second, but no less important objective of the research is the identification of factors which were the driving forces of these changes. In particular, what was the impact of factors related to European integration?

With reference to the research objectives hypotheses were formulated. Firstly, it was assumed that the changes in the economic position of Polish cities which took place during the last two decades would allow for the identification of the group of "success cities" and "loser cities". The identification of the key drivers of changes in the "success cities" may be slightly more difficult than for "loser cities". Factors that negatively influence the economic position of cities can be somewhat more grouporiented and it could be easier to identify them.

In relation to the second objective it is assumed that particular factors could have been crucial for explaining changes in the economic positions of cities:

1. The impact of the process of European integration. Access to EU funds (including pre-accession funds) and economic integration, as well as the exchange of academic staff have contributed to the change in the level of the economic development of Polish cities. In the context of integration, the role of social capital (participation in the European Parliament elections) should not be insignificant to the economic development of cities.

Results of studies on European countries indicate the role of integration processes, particularly trade integration in the development of industry in the EU (Krugman \& Venables 1996; Tsiapa 2014).

2. Location in relation to the main city agglomeration and to airports - theories of location of economic activity show the importance of proximity of agglomerations and central places in the economic development of cities; see, e.g. Weber agglomeration factor (1909); Christaller theory of central places (see, e.g. Kuciński 2004);

3. The administrative status of the city - losing the status of a regional capital may have negative consequences for the economic development of a city. According to Dasher (2000), capitals of regions or counties grow faster than other cities in the same area. As regards the capitals of the EU countries, it was empirically proven by Cuaresma et al. (2014);

4. Degree of sectoral diversification of cities' economy cities that based their economy on one industry (especially a declining industry) are exposed to the risk of negative changes in their economic position (Noseleit 2013);

5. Human capital and social capital - there is much evidence from previous research on the impact of factors related to the quality of human capital and social capital on economic development (Nelson \& Phelps 1966; Putnam 1993; Francois 2002; Coffé \& Geys 2005; Cullinan et al. 2014). For Poland, there are several papers on the impact of institutions and social capital on urban economic development (see, e.g. Dziemianowicz et al. 2011; Łukomska 2012);

6. State of the modernization of the private sector - cities experiencing positive changes in the private sector and the development of local businesses, have a chance to improve their economic position in the hierarchy of cities. In particular, large and prosperous businesses remain important for the local economy (Śleszyński 2008). In the era of rapid technological progress, investments in fixed assets are extremely important for shaping the competitive advantage of enterprises (Czerwonka \& Jaworski 2014). The importance of investments in fixed assets for the development of Polish enterprises has been shown in the research of Kotowicz-Jawor (2001) or Duda (2009). Business development is taking place with the expansion of the market to other countries through export. The weight of exports for the development of the local economy was analyzed by Komornicki (2009).

\section{Dataset and method}

The dataset consists of 91 Polish relatively big cities which at the beginning of 1990 had a population of more than 50 thousand. The intention was to have a starting point for the analysis at the 
beginning of economic and political transformation in Poland. The first year for which comparable data is available is not 1990 but 1992; thus, the starting point for empirical analysis is 1992.

The database for these cities was built for five points in time, which can be considered important for socio-economic changes in Poland:

1992 - the beginning of transformation (the earliest available, comparable and complete data);

1998 - an administrative and territorial reform resulting in a reduced number of regions (16 new regions were implemented instead of 49 regions); many big cities lost the administrative status of a regional capital;

2004 - Poland's accession to the European Union;

2008 - Poland entered the Schengen area, the movement of people and goods within the area has become easier;

2013 - the newest available data at the moment of conducting the empirical analysis.

Despite numerous empirical studies, development practitioners and academics have not succeeded in developing a uniform and coherent method of comprehensive measurement of economic development. Most often, as pointed out by M. Obrębalski, the measurements used are dependent on the arbitrariness of the research team's approach and information possibilities (Obrębalski 2002).

The first idea was to take into account the most popular indicator of economic growth - GDP per capita. Unfortunately, data on GDP are not available in Poland at the local level (for cities/municipalities). The analysis using this indicator could cover only the six largest Polish cities: Warsaw, Kraków, Łódź, Wrocław, Poznań and Szczecin (which have NUTS3 status). Finally, taking into account the definition of development as a complex process, several variables were used to construct a synthetic (composite) index. Synthetic indices for 91 cities were constructed for five points in time: 1992, 1998, 2004, 2008 and 2013. Static measures for each given year were used (instead of dynamic indicators) to avoid methodological problems. A simple method for creating synthetic indicators was implemented. It was one of the linear ordering methods called "Z. Hellwig method" (so-called taxonomic measure of development understood as the arrangement of units investigated depending on their distance from a certain artificially constructed point). This method was repeatedly used to measure development phenomena (see, e.g. Łukomska 2012; Pomianek 2010).

The hierarchy index $(\mathrm{HI})$ was constructed of five variables: population, unemployment rate, local budget revenues from personal income tax per capita and measure of local businesses based on local budget revenues from corporate income tax and commercial property tax base per capita. The latter two variables measure the same dimension, which was taken into account by the appropriate weights of variables. All component variables except for the unemployment rate are treated as the stimulants. The indices were calculated according to the following formula:

$\mathbf{H}=\sqrt{\sum(x(i, j)-x(i, \max ))^{2}}$

where:

$\mathrm{HI}$ - hierarchy index

$x(i, j)$ - standardized value of variable $i$ for unit $j$ (standardization performed with z-score method ${ }^{1}$ );

$x(i, \max )$ - the "best" value (the highest or the lowest, depending on the nature of the variable) within an analyzed sample of

\footnotetext{
1 The $z$-score formula is the following: $z(\mathrm{ij})=\frac{x(j)-\overline{x(i)}}{d(x(i)}$, where $z(\mathrm{ij})-$ standardized value, $\mathrm{x}(\mathrm{ij})$ - "original" value of variable $\mathrm{i}$ for city $\mathrm{j}, \overline{x(i)}$ - mean value of the variable $\mathrm{i}$ for all cities, $d(x(i))-$ standard deviation of the variable i. Such a standardized variable always has mean $=0$ and standard deviation $=1$.
}

the standardized value of variable i. These "best" values were identified for each year under analysis. For this reason, the article analyzes the positions of cities in the individual rankings rather than the values of $\mathrm{HI}$.

The constructed indicators are based on data from the Central Statistical Office and Ministry of Finance (financial reports on the budget execution of municipalities).

In the next stages of the research, the Pearson correlation and regression analyses (OLS and hierarchical OLS) were used. In the case of the multiple linear regression method (OLS), a progressive selection method is used, which consists of a sequential selection of independent variables for the model. The next step of the analysis is based on a hierarchical multiple regression analysis which is a framework for model comparison rather than a statistical method. The procedure involves entering sets of explanatory variables into the model in blocks and allows to test whether the addition of each block has improved the model's match to the data over the previous blocks.

The main dependent variable (change 1992-2013) is characterized by normal distribution, while the distributions of two other dependent variables are a bit skew but not significantly.

\section{Changes in the urban hierarchy}

On the basis of the obtained values of $\mathrm{HI}$, the five rankings of the economic position of cities for each of five points in time were created. The next step was the comparison of all five hierarchies, checking which groups of cities are ascending and which are descending the hierarchy.

Which of the analyzed cities made the biggest "leap" in the rankings in 1992-2013? The not very big cities (with less than 80 thousand inhabitants, except Koszalin) within the group of cities experienced the most significant positive changes. They are not concentrated in a given region, but are quite evenly distributed throughout the country. At first glance, it is hard to find distinctive features of this group. This is not the case for the group of cities that lost their economic position dramatically between 1992 and 2013. These are mono-industrial cities located in the Upper Silesia, usually with the dominance of the mining industry in the structure of their economy (see Table 1).

How did the rankings change over the years? The analysis has covered the changes in all possible combinations for the above five points over time: 1992-1998, 1992-2004, 1992-2008, 1992-2013, 1998-2004, 1998-2008, 1998-2013, 2004-2008, 2004-2013 and 2008-2013. It was assessed whether there is

Table 1. Greatest gain and greatest loss of cities in the ranking 1992-2013

\begin{tabular}{|c|c|c|c|c|}
\hline & \multicolumn{2}{|c|}{$\begin{array}{c}\text { Greatest gain } \\
\text { 1992-2013 }\end{array}$} & \multicolumn{2}{c|}{$\begin{array}{c}\text { Greatest loss } \\
\text { 1992-2013 }\end{array}$} \\
\hline 1 & Kutno & +43 & Racibórz & -60 \\
\hline 2 & Piła & +36 & Bytom & -51 \\
\hline 3 & Bełchatów & +35 & Świętochłowice & -46 \\
\hline 4 & Koszalin & +35 & Zabrze & -38 \\
\hline 5 & Głogów & +34 & $\begin{array}{c}\text { Siemianowice } \\
\text { Śląskie }\end{array}$ & -35 \\
\hline 6 & Puławy & +30 & Jastrzębie-Zdrój & -35 \\
\hline 7 & Świdnica & +27 & Ruda Śląska & -32 \\
\hline 8 & Pruszków & +27 & Wodzisław Śląski & -31 \\
\hline 9 & Siedlce & +25 & Piekary Śląskie & -31 \\
\hline 10 & Radomsko & +25 & Zawiercie & -27 \\
\hline
\end{tabular}

Source: own calculations 
Table 2. Pearson correlation coefficients among changes of position in rankings

\begin{tabular}{|c|c|c|c|c|c|c|c|c|c|}
\hline & \multicolumn{9}{|c|}{ Changes: } \\
\hline & 1992-1998 & $1992-2004$ & $1992-2008$ & 1998-2004 & 1998-2008 & $1998-2013$ & 2004-2008 & 2004-2013 & 2008-2013 \\
\hline $\begin{array}{c}\text { Change } \\
1992- \\
2013\end{array}$ & $+0.65^{\star * *}$ & $+0.90^{* \star *}$ & $+0.91^{* \star *}$ & $+0.73^{\star \star *}$ & $+0.70^{* * *}$ & $+0.85^{\star \star *}$ & 0.10 & $+0.39^{* * *}$ & $+0.31^{\star * *}$ \\
\hline
\end{tabular}

Note: ${ }^{* *}$ means significance at the 0.001 level

Source: own calculations

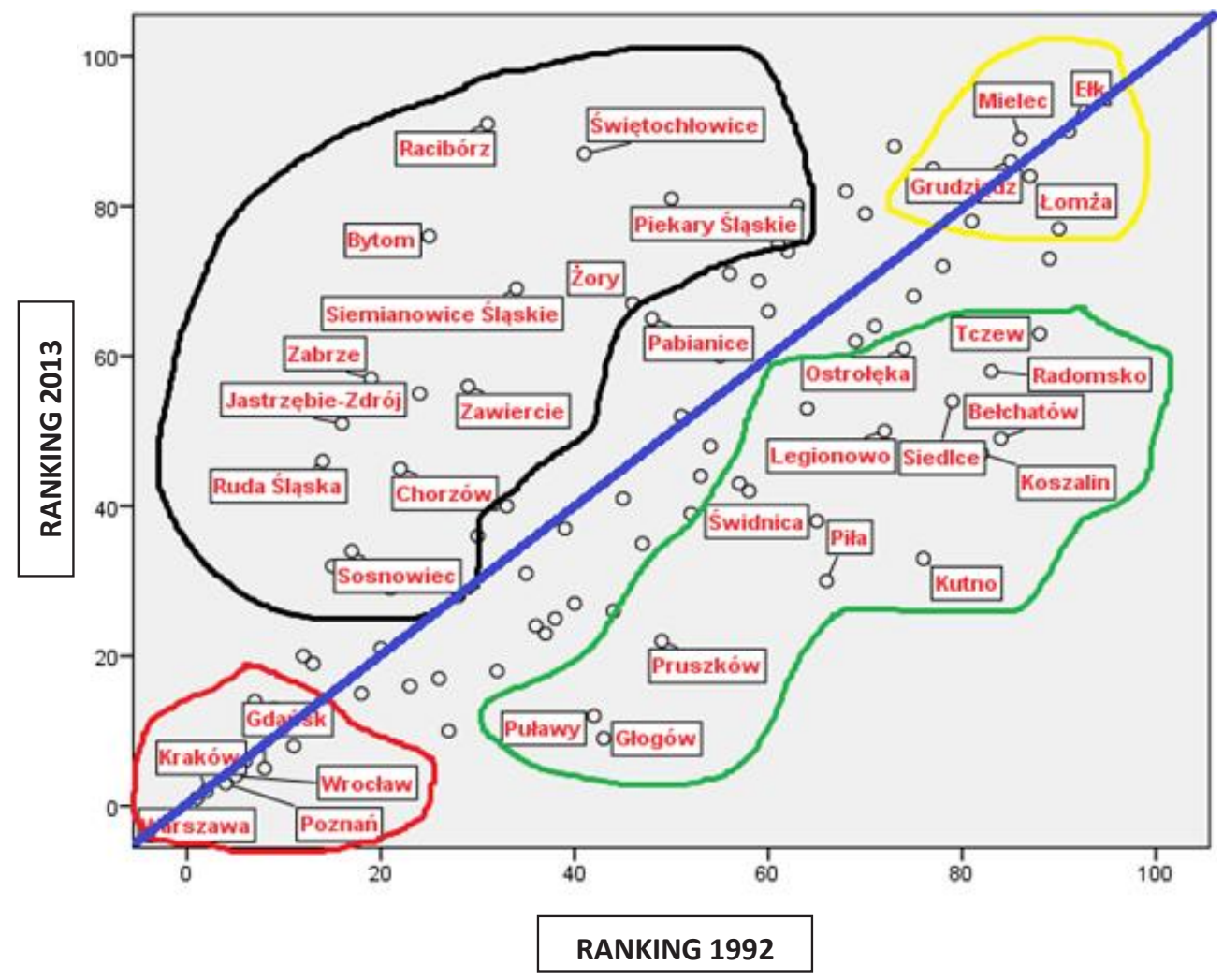

Figure 1. Four groups of Polish big cities separated due to the change in the economic position between the ranking from 1992 and 2013 Source: own calculations

a relationship between the changes in these periods. Changes in almost all configurations are correlated with the 1992-2013 change. The only exception is the 2004-2008 change (Table 2). Changes in this period do not show a statistically significant relationship with the changes in the whole period of 1992-2013, and this may suggest that the economic changes in cities immediately after Poland's accession to the EU were slightly different from the overall trend of changes throughout the analyzed period.

If we compare the cities in the 1992 ranking with the 2013 ranking, we can identify four groups of cities (see Figure 1). This diagram is a sort of summary of the first part of the empirical study.

The first group of cities (in the lower left corner of the diagram) - throughout the entire period this group kept its leading place in the ranking of economic development. These are the largest Polish cities. Their position in the hierarchy is stable.

The second group (cities in the upper left corner of the diagram) - their loss was the most dramatic in the rankings. This group comprises almost exclusively mining cities located in Upper Silesia.

The third group (cities in the bottom right corner of the diagram) - they have improved their positions in the rankings between 1992 and 2013. It is difficult to identify distinctive features of these cities. Some of them are very characteristic, e.g. with one large and very prosperous state company located there: Głogów (producer of copper and refined silver - KGHM Polska Miedź S.A.), Puławy (one of the largest melamine producers in the world and the biggest Polish company in the field of chemical synthesis - "Azoty Group Puławy" S.A.).

The fourth group are cities that have maintained a poor ranking for years.

The cities from the second and third group which were described above are the subject of quantitative analyses, as the dependent variables of the models tested are changes in the ranking (in the case of the first and fourth group of cities there 
MISCELLANEA GEOGRAPHICA - REGIONAL STUDIES ON DEVELOPMENT

Vol. $22 \cdot$ No. $1 \cdot 2018 \cdot$ pp. 48-55 •ISSN: 2084-6118 • DOI: 10.1515/mgrsd-2017-0035

Table 3. Operationalisation of factors explaining changes in economic hierarchies of Polish large cities

\begin{tabular}{|c|c|c|}
\hline & $\begin{array}{ll}\text { Explanatory variables } \\
\end{array}$ & Expected sign \\
\hline $\begin{array}{l}\text { European } \\
\text { integration }\end{array}$ & 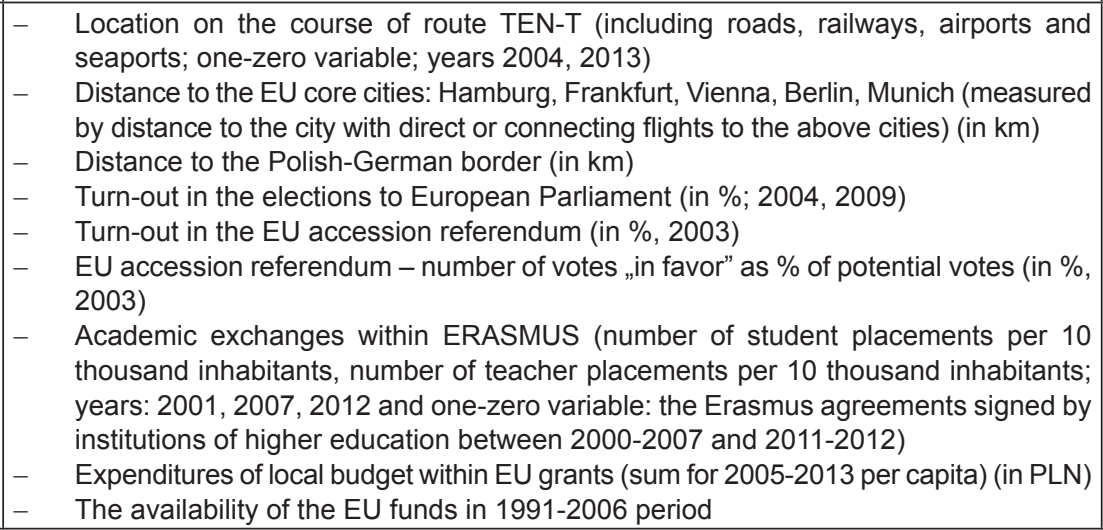 & $\begin{array}{l}- \\
- \\
+ \\
+ \\
+ \\
+\end{array}$ \\
\hline Location & 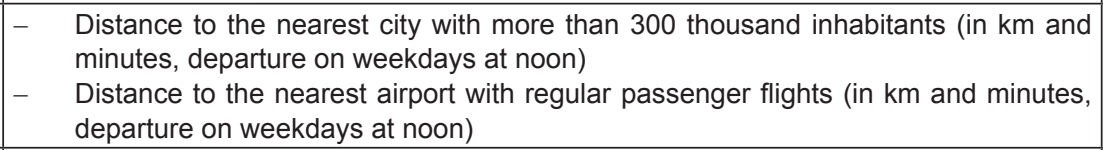 & - \\
\hline $\begin{array}{l}\text { Degree of sectoral } \\
\text { diversification of } \\
\text { cities' economy }\end{array}$ & $\begin{array}{l}\text { - } \quad \text { Local budget revenues from fee on exploitation of natural resources (minerals) over } \\
\text { PLN 200,000 (one-zero variable; } 2004,2008,2013 \text { ) }\end{array}$ & - \\
\hline Human capital & 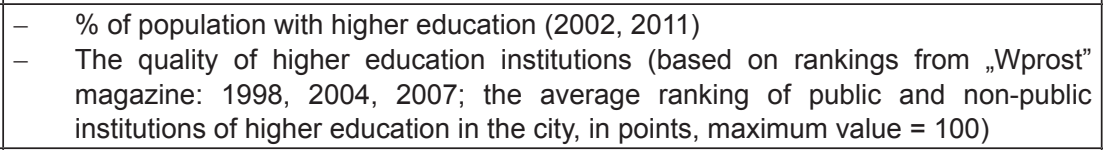 & $\begin{array}{l}+ \\
+\end{array}$ \\
\hline Social capital & $\begin{array}{|ll|}- & \text { Turn-out in local elections (in \%; 1990,1994,1998,2002,2006,2010) } \\
- & \text { The number of NGO's per capita }(1995,1998,2004,2008,2013) \\
\end{array}$ & + \\
\hline $\begin{array}{l}\text { Administrative } \\
\text { status }\end{array}$ & - $\quad$ Losing the status of regional capital (one-zero variable, 1998) & - \\
\hline $\begin{array}{l}\text { Modernisation of } \\
\text { private sector }\end{array}$ & $\begin{array}{ll}- & \text { Change in gross value of fixed assets in enterprises (2004-2013, in \%) } \\
- & \text { The number of firms from the list of } 500 \text { of the biggest companies in the country } \\
\text { located within the city per } 100 \text { thousand inhabitants (based on the rankings from } \\
\text { „Polityka” magazine; 1998, 2012) } \\
\text { - The value of exports per capita (in PLN; 2005, 2007) }\end{array}$ & $\begin{array}{l}+ \\
+\end{array}$ \\
\hline
\end{tabular}

Source: own elaboration

were no changes, or the changes were insignificant).

Factors explaining changes in urban hierarchies

Factors that can determine changes in the hierarchy of cities have been described and theoretically embedded in the section with the explanation of the research hypothesis. The next step was the operationalization of these factors. Finding the available data, which would be a good measure of the individual factors, was not an easy task, so in the case of selected factors some assumptions were needed. At this stage, in addition to data from the Main Statistical Office and data from the Ministry of Finance, databases specially prepared for this study were used, i.a. location in the context of communication accessibility, student and teacher mobility within the ERASMUS program, the quality of universities and the location of the biggest 500 companies on the basis of information available in "Wprost" and "Polityka" magazines. The data on the availability of EU funds for local governments in Poland in 1991-2006 prepared by K. Szmigiel (2007) and data on exports based on Komornicki's work (2009) were also used.

The list of variables operationalizing the factors explaining changes in the economic development of cities in the groups is presented in Table 3.

The results of the regression analysis with respect to the three explanatory variables (changes of the city's ranking in
1992-2013, 1992-2004 and 2004-2013) are presented in Table 4.

The explanatory power of the models tested is not very high (from about $20 \%$ in the case of explaining changes in 2004-2013 to about $60 \%$ in the model explaining the change in 1992-2004). Many of the independent variables were not statistically significant for explaining the changes in the economic position of cities ${ }^{2}$.

However, among the variables that are not irrelevant to the shifts in the economic hierarchy, the factors related to European integration can be found. These are the variables related to the availability of communication in relation to the core cities of the European Union:

- location in relation to the airports in Hamburg and Munich - the closer to these cities, the more positive the change in the hierarchy of economic development;

- location of the city on the TEN-T rail network - the cities on the main international rail lines (AGC) and the important international combined transport lines (AGTC) experienced an improvement in economic development between 2004 and 2013.

The results show that the closer to Vienna, the more negative the change in the economic development of the city. This result of

${ }^{2}$ They were excluded from the explanatory models during the statistical procedure. 
Table 4. Results of OLS regression analyses (progressive selection method)

\begin{tabular}{|c|c|c|c|}
\hline & \multicolumn{3}{|c|}{ Dependent variable } \\
\hline & $\begin{array}{c}\text { Change in } \\
\text { the ranking } \\
1992-2013\end{array}$ & $\begin{array}{c}\text { Change in } \\
\text { the ranking } \\
1992-2004\end{array}$ & $\begin{array}{l}\text { Change in } \\
\text { the ranking } \\
2004-2013\end{array}$ \\
\hline R square & 0.552 & 0.623 & 0.213 \\
\hline Adjusted $\mathrm{R}$ square & 0.513 & 0.580 & 0.185 \\
\hline Significance of the model & 0.000 & 0.000 & 0.000 \\
\hline \multicolumn{4}{|l|}{ Explanatory variables } \\
\hline Distance to the airport in Vienna by plane & $0.469^{* * *}$ & & \\
\hline$\%$ of population with higher education 2002 & $0.370^{* * *}$ & $0.203^{*}$ & \\
\hline TEN-T (location of the airport in the city) & $-0.271^{\star *}$ & & \\
\hline Turn-out in local elections 1998 & $0.332^{* \star}$ & & \\
\hline The value of export per capita 2005 & $0.203^{*}$ & & \\
\hline Distance to the airport in Hamburg & $-0.214^{*}$ & & \\
\hline Losing the status of regional capital & & $0.216^{* *}$ & \\
\hline Turn-out in local elections 1990 & & $-0.471^{* * *}$ & \\
\hline Turn-out in local elections 1994 & & $0.282^{*}$ & \\
\hline Distance to the city with direct flight to Munich & & $-0.198^{*}$ & \\
\hline Distance to the nearest city with more than 300 thousand inhabitants (in minutes) & & $0.312^{* *}$ & \\
\hline Turn-out in the elections to European Parliament in 2003 (w \%) & & $0.672^{* * *}$ & \\
\hline Number of votes „in favor” as \% of potential votes in EU accession referendum & & $-0.396^{* *}$ & \\
\hline Change in gross value of fixed assets in enterprises per capita $2004-2013$ & & & $0.385^{* * *}$ \\
\hline TEN-T (railway) & & & $0.235^{*}$ \\
\hline The availability of the EU funds in 1991-2006 period & & & $0.217^{*}$ \\
\hline
\end{tabular}

Note: * - significance at the 0.05 level * * significance at the 0.01 level * * ${ }^{*}$ significance at the 0.001 level

Source: own calculations

regression analyses could be related to a group of cities located in Upper Silesia that can be characterized by negative economic changes and quite a short distance from the airports nearest to the airport in Vienna (Katowice or Kraków).

Among variables that are statistically significant to explaining the changes in the rankings were also the variables related to European integration, such as the turnout in the accession referendum (the higher the turnout in the city, the more positive the change in the ranking of $1992-2004^{3}$ ) and the availability of EU funds for local governments in the years 1991-2006 (the higher the rate of availability of EU funds, including pre-accession funds, the more positive the change in the years 2004-2013).

The relevance of "European integration" factors is confirmed by a hierarchical multiple regression analysis, but only for the model with the dependent variable related to the change of 1992-2013. Only for this period, the adding of a "European integration" block of variables to the model increased its explanatory power in a statistically significant way (at $5 \%$ level) (Table 5).

The variables related to human and social capital (\% of population with higher education and electoral turnout in

"However, the percentage of votes "in favor" as a percentage of potential votes in the 2003 referendum turned out to be a variable negatively correlated with economic changes in the period 1992-2004. This would indicate that the cities that experienced positive changes in the rankings in the 1990s and in the beginning of the 21st century were characterized by a relatively smaller group of Euro-Med participants in the accession referendum.
1994 and 1998 local elections ${ }^{4}$ ) proved to be important for the economic change. Also, the modernization of the private sector (the value of export per capita and the change in the per capita value of fixed assets ${ }^{5}$ ) turned out to be the predictor of a positive change in the economic hierarchy.

The loss of the administrative status of the regional capital turned out to be a variable explaining changes in the economic hierarchy of cities in 1992-2004. This relationship is positive, which means that cities holding the status of a regional capital in the period 1992-1998 have experienced positive changes in their economic positions between 1994 and 2004 (see Table 5).

\section{Conclusions}

According to the results of the research, it is easier to identify the factors that played a key role in the loss of the economic position of cities. There is the group of Upper Silesian cities, dominated by the coal mining industry (with industrial monoculture). The economic transformation of the 1990s hit this group of cities quite hard. Coal began to lose popularity (initially lignite and later other sources of energy were introduced, as well as regulations limiting $\mathrm{CO} 2$ emissions). Problems began in the first half of the 1990s. It turned out that coal mining in

\footnotetext{
${ }^{4}$ Although the results regarding turnout are not clear, the turnout in the local elections of 1990 is negatively correlated with changes in the city's economic hierarchy. But this election was exceptional in many respects, e.g. high percentage of invalid votes (Gendźwił 2014)

${ }^{5}$ The variable was statistically significant in the period 2004-2013.
} 
MISCELLANEA GEOGRAPHICA - REGIONAL STUDIES ON DEVELOPMENT

Vol. $22 \cdot$ No. $1 \cdot 2018 \cdot$ pp. 48-55 • ISSN: 2084-6118 • DOI: 10.1515/mgrsd-2017-0035

Table 5. Changes in the explanatory power of regression models after adding the variables related to EU integration (hierarchical multiple regression)

\begin{tabular}{|c|c|c|c|}
\hline & \multicolumn{3}{|c|}{ Dependent variable } \\
\hline & $\begin{array}{c}\text { Change in the ranking } \\
\mathbf{1 9 9 2 - 2 0 1 3}\end{array}$ & $\begin{array}{c}\text { Change in the ranking } \\
\mathbf{1 9 9 2 - 2 0 0 4}\end{array}$ & $\begin{array}{c}\text { Change in the ranking } \\
\mathbf{2 0 0 4} \mathbf{- 2 0 1 3}\end{array}$ \\
\hline Significance of the model & 0.001 & 0.000 & 0.306 \\
\hline R square & 0.578 & 0.612 & 0.366 \\
\hline $\begin{array}{c}\text { R square after entering to the model block of „EU } \\
\text { integration” variables }\end{array}$ & 0.868 & 0.765 & 0.715 \\
\hline R square change & 0.290 & 0.153 & 0.349 \\
\hline Significance of R square change & $\mathbf{0 . 0 2 9}$ & 0.075 & 0.401 \\
\hline
\end{tabular}

Source: own calculations

Poland was too expensive. The first layoffs of miners started, the miners joined the unemployed, and later they became long-term unemployed. The negative effects of these processes are evident when we compare the dynamics of the changes in the indicators. It shows that these cities have depreciated more than others, and that the problems of unemployment and falling incomes have affected these cities more noticeably than the others. The monostructure model of these cities, which focus too intently on one branch of economic growth, makes them vulnerable to rapid decline. As a result, a notable population loss could be observed. This phenomenon was identified and broadly presented in the literature within the research on shrinking cities (Hollander \& Németh 2011). As the research of German regions shows, even when new companies are established, this does not reflect in economic growth as much as it does in more economically diversified cities (Noseleit 2013).

It is difficult to identify the "success factors" that have allowed cities to make the most positive changes in the ranking. Probably the individual characteristics of these cities, which were not captured in statistical analyses, were crucial. During the investigation it turned out that the "success" of cities was related to the presence of a single large state owned and successful company. But the results of the regression analysis did not confirm the significance of the number of firms from the list of 500 biggest companies in the country. Probably this result could be explained by the domination of the only one prosperous company which is important to the local market in relatively smaller cities. But simultaneous consideration of the dominance and economic condition of the company was difficult to capture in statistical models.

Nevertheless, it is interesting to note that the factors related to European integration have been shown as important to explaining the changes in the economic hierarchy of Polish cities. In addition to location variables, the availability of EU funds for local governments has proved to be important. Cities that were able to benefit from EU funds in the period 1991-2006 (including the pre-accession funds) in the years 2004-2013, experienced a more positive change in the economic hierarchy than the other cities. This relationship could be associated with the location issue. Most EU funds were available in regions near the western border during accession and pre-accession phases. However, the variable "distance from the western border" turned out to be insignificant when explaining changes in the economic positions of cities.

It is known from earlier studies that variables related to social and human capital are usually very significant in the context of economic development. The results of the conducted research suggest that they are also important for explaining changes in the hierarchy of Polish cities in the analyzed period of time.

Changes in the value of fixed assets in enterprises per capita turned out to be an important variable explaining the changes in the ranking in the years 2004-2013. As indicated by the results of other research, fixed assets in 2001-2010 were the main investment direction of Polish enterprises, accounting for more than half of the total investment. Most fixed assets purchased by companies during this period were new assets. The most dynamically growing expenditures where those financed by budgetary resources - grants from local governments and central government (increase of $190 \%$ ) and by foreign funds (60\%). This was probably related to the launching of investment EU aid programs aimed at enterprises in the post-accession period (Czerwonka, Jaworski 2014).

\section{Acknowledgment}

The empirical investigation presented in the article has been conducted as part of the research project "East-German and Polish Cities in the Process of European Integration (CITIN)" (project no. 2014-17, application no. 100272), funded by the German-Polish Scientific Foundation.

\section{References}

Bröcker, J 2009, 'Städtesystem und Globalisierung' in Metropolregionen: Innovation, Wettbewerb, Handlungsfähigkeit, ed J Knieling, ARL, Hannover.

Cheshire, P 1999, 'Cities in competition: articulating the gains from integration', Urban Studies, vol. 36 (5/6), pp. 843-864.

Coffé, H \& Geys, B 2005, 'Institutional performance and social capital: an application to the local government level', Journal of Urban Affairs, vol. 27 (5), pp. 485-501.

Cuaresma, CJ, Doppelhofer, G \& Feldkircher, M 2014, 'The determinants of economic growth in European regions', Regional Studies, vol. 48(1), pp. 44-67.

Cullinan, J, Garvey, E \& Keane, M 2013, 'Investigating the determinants of relative economic performance for Irish towns: a finite mixture modelling approach', Regional Studies, vol. 47 (8), pp. 1332-1347.

Czerwonka, L \& Jaworski, J 2014, 'Inwestycje polskich podmiotów gospodarczych w środki trwałe i źródła ich finansowania w latach 2001-2010', Zeszyty Naukowe Uniwersytetu Szczecińskiego, no. 804, Finanse, Rynki Finansowe, Ubezpieczenia no. 67, pp. 279-293

Dascher, K 2000, Are politics and geography related?: Evidence from a cross-section of capital cities', Public Choice, vol. 3/4, pp. 373-392.

Duda, J 2009, 'Decyzje inwestycyjne przedsiębiorstw polskich z sektora MŚP', Prace Naukowe Uniwersytetu Ekonomicznego we Wrocławiu, no. 48. 
Dziemianowicz, W 2008, Konkurencyjność gmin w kontekście relacji władze lokalne - inwestorzy zagraniczni, Wydawnictwo Uniwersytetu Warszawskiego, Warszawa.

Dziemianowicz, W, Szlachta, J \& Szmigiel-Rawska, K (eds) 2011, Subregionalne bieguny wzrostu w Polsce, Wydział Geografii i Studiów Regionalnych Uniwersytetu Warszawskiego, Warszawa.

Francois, P 2002, Social Capital and Economic Development, Routledge, London.

Gendźwiłł, A 2014, 'Wybory 2014: co wywołało kontrowersje, czego możemy się nauczyć?', in Wybory: wiarygodność i sprawność, ed P Kosiewski, Warszawa: Fundacja im. Stefana Batorego, pp. 31-45.

Gorzelak, G \& Olechnicka, A 2009, Polska z perspektywy badań ESPON - oceny, wnioski, rekomendacje, Warszawa.

Hollander, J \& Németh, J 2011, The bounds of smart decline: a foundational theory for planning shrinking cities', Housing and Policy Debate, vol. 21 (3), pp. 349-367.

Komornicki, T 2009, Ocena charakteru, struktury, i intensywności polskiego eksportu w kontekście celów polityki regionalnej, na poziomie województw w ujęciu dynamicznym, Ministerstwo Rozwoju Regionalnego, Warszawa.

Kotowicz-Jawor, J 2001, Szanse rozwojowe przedsiębiorstw', Ekonomia, no. 1.

Krugman, P \& Venables, A 1996, Integration, specialization and adjustment', European Economic Review, vol. 40, pp. 959967.

Kuciński, K 2004, Geografia ekonomiczna. Zarys teoretyczny, SGH, Warszawa.

Kunze, C \& Lenk, T 2007, Großstädte im Transformationsprozess vor dem Hintergrund europäischer Integration und internationalen Strukturwandels: Leipzig und Wrocław 2000 bis 2004 im Vergleich, Leipzig.

Łukomska, J 2012, 'Czynniki lokalnego rozwoju gospodarczego w Polsce' in Badania regionalnych $i$ lokalnych struktur przestrzennych, ed D Ilnicki \& K. Janc, Uniwersytet Wrocławski, Wrocław, pp. 45-57.

Ministerstwo Rozwoju Regionalnego 2010, Wpływ funduszy europejskich na gospodarke polskich regionów $i$ konwergencje z krajami UE, MRR, Warszawa

Nelson, R \& Phelps, E 1966, Investment in humans, technological diffusion, and economic growth', American Economic Review, no. 56.
Niebuhr, A \& Stiller, S 2004, 'Integration effects in border regions - a survey of economic theory and empirical studies', Jahrbuch für Regionalwissenschaft, vol. 24 (1), pp. 3-21.

Noseleit, F 2013, 'Entrepreneurship, structural change, and economic growth', Journal of Evolutionary Economics, vol. 23, pp. 735-766.

Obrębalski, M 2002, 'Rozwój regionalny - identyfikacja, pomiar i ocena' in Gospodarka lokalna w teorii i w praktyce, ed E Sobczak, Wydawnictwo Akademii Ekonomicznej we Wrocławiu, Wrocław, pp. 11-19.

Pomianek, I 2010, Poziom rozwoju społeczno-gospodarczego obszarów wiejskich województwa warmińsko-mazurskiego', Acta Oeconomia, no. 9 (3), pp. 227-239.

Putnam, R 1993, Making Democracy Work: Civic Traditions in Modern Italy, Princeton.

Swianiewicz, P, Krukowska, J \& Lackowska, M 2013, Profesjonalizacja absorpcji funduszy. Beneficjenci samorządowi centralnie zarządzanych programów operacyjnych w okresie 2007-2013, Ministerstwo Rozwoju Regionalnego, Warszawa.

Szmigiel, K 2007, Pomoc zewnętrzna skierowana do samorządów lokalnych w Polsce w okresie transformacji' in Gmina pasywna, ed W Dziemianowicz \& P Swianiewicz, Studia KPZK PAN, vol. CXVII, Warszawa, pp. 39-55, pp. 176-183.

Śleszyński, P 2007, Gospodarcze funkcje kontrolne w przestrzeni Polski', Prace Geograficzne, vol. 213, Instytut Geografii i Przestrzennego Zagospodarowania PAN, Warszawa.

Śleszyński, P 2008, Duże przedsiębiorstwa w strukturze przestrzennej największych polskich miast', Prace Geograficzne, vol. 217, Instytut Geografii i Przestrzennego Zagospodarowania PAN, Warszawa.

Tsiapa, M 2014, Industrial growth in the Integrated European Economic Space', Organizations and Markets in Emerging Economies, vol. 5, no. 2(10), pp. 23-43.

Weber, A 1909, Über den Standort der Industrie, Tübingen.

Węcławowicz, G, Łotocka, M \& Baucz, A 2010, Rozwój miast w Polsce, Raport wprowadzający Ministerstwa Rozwoju Regionalnego opracowany na potrzeby przygotowania Przeglądu OECD Krajowej Polityki Miejskiej w Polsce, Ministerstwo Rozwoju Regionalnego, Warszawa. 